\title{
TREE SPECIES EFFECTS ON DECOMPOSITION AND FOREST FLOOR DYNAMICS IN A COMMON GARDEN
}

\author{
Sarah E. Hobbie, ${ }^{1,4}$ Peter B. Reich, ${ }^{2}$ Jacek Oleksym,${ }^{2,3}$ Megan Ogdahl,,${ }^{1}$ Roma Zytkowiak, ${ }^{3}$ Cynthia Hale, ${ }^{2}$ \\ and Piotr Karolewski ${ }^{3}$ \\ ${ }^{1}$ Department of Ecology, Evolution, and Behavior, University of Minnesota, St. Paul, Minnesota 55108 USA \\ ${ }^{2}$ Department of Forest Resources, University of Minnesota, St. Paul, Minnesota 55108 USA \\ ${ }^{3}$ Polish Academy of Sciences, Institute of Dendrology, PL-62-035 Kornik, Poland
}

\begin{abstract}
We studied the effects of tree species on leaf litter decomposition and forest floor dynamics in a common garden experiment of 14 tree species (Abies alba, Acer platanoides, Acer pseudoplatanus, Betula pendula, Carpinus betulus, Fagus sylvatica, Larix decidua, Picea abies, Pinus nigra, Pinus sylvestris, Pseudotsuga menziesii, Quercus robur, Quercus rubra, and Tilia cordata) in southwestern Poland. We used three simultaneous litter bag experiments to tease apart species effects on decomposition via leaf litter chemistry vs. effects on the decomposition environment. Decomposition rates of litter in its plot of origin were negatively correlated with litter lignin and positively correlated with mean annual soil temperature (MAT $\left.\mathrm{Moil}_{\text {sil }}\right)$ across species. Likewise, decomposition of a common litter type across all plots was positively associated with $\mathrm{MAT}_{\text {soil }}$, and decomposition of litter from all plots in a common plot was negatively related to litter lignin but positively related to litter Ca. Taken together, these results indicate that tree species influenced microbial decomposition primarily via differences in litter lignin (and secondarily, via differences in litter $\mathrm{Ca}$ ), with high-lignin (and low-Ca) species decomposing most slowly, and by affecting $\mathrm{MAT}_{\text {soil }}$, with warmer plots exhibiting more rapid decomposition. In addition to litter bag experiments, we examined forest floor dynamics in each plot by mass balance, since earthworms were a known component of these forest stands and their access to litter in litter bags was limited. Forest floor removal rates estimated from mass balance were positively related to leaf litter $\mathrm{Ca}$ (and unrelated to decay rates obtained using litter bags). Litter $\mathrm{Ca}$, in turn, was positively related to the abundance of earthworms, particularly Lumbricus terrestris. Thus, while species influence microbially mediated decomposition primarily through differences in litter lignin, differences among species in litter $\mathrm{Ca}$ are most important in determining species effects on forest floor leaf litter dynamics among these 14 tree species, apparently because of the influence of litter $\mathrm{Ca}$ on earthworm activity. The overall influence of these tree species on leaf litter decomposition via effects on both microbial and faunal processing will only become clear when we can quantify the decay dynamics of litter that is translocated belowground by earthworms.
\end{abstract}

Key words: calcium; decomposition; earthworms; lignin; litter; $N$-immobilization; Poland; trees.

\section{INTRODUCTION}

Ecosystem ecology has a rich history of studies relating decomposition of leaf litter to its chemistry. For example, variation in decomposition rate among plant species is often positively related to initial nitrogen (N) concentrations and negatively related to initial lignin concentrations (e.g., Meentemeyer 1978, Melillo et al. 1982, Aerts 1997). Although there are exceptions, this general pattern of lignin and/or $\mathrm{N}$ control over decomposition rates has been demonstrated in a wide variety of ecosystems (Van Cleve 1974, McClaugherty and Berg 1987, Taylor et al. 1991, Hobbie 1996, Austin and Vitousek 2000), and we refer to it hereafter as the lignin-N paradigm.

Manuscript received 21 September 2005; revised 21 February 2006; accepted 7 March 2006. Corresponding Editor: J. B. Yavitt.

${ }^{4}$ E-mail: shobbie@umn.edu
Substrate chemistry, along with site factors, also contributes to species differences in $\mathrm{N}$-immobilization into decomposing litter. For example, some studies have shown greater immobilization in litter with low initial $\mathrm{N}$ concentrations (Berg and Eckbom 1983, Hobbie and Vitousek 2000, Schwendener et al. 2005; but see Pastor et al. 1987). Other studies suggest that initial lignin concentration determines $\mathrm{N}$-immobilization (Melillo et al. 1982).

Relationships of litter lignin and $\mathrm{N}$ to decomposition and litter $\mathrm{N}$ dynamics, although not universal, pervade thinking about species effects on biogeochemistry (Vitousek 1982, Hobbie 1992, Scott and Binkley 1997, Berendse 1998) and form a basis for many ecosystem models. For example, the partitioning of litter into different detrital pools and the decay constants assigned to those pools often depends on litter lignin or lignin : $\mathrm{N}$ ratios (Moorehead et al. 1996). 
Besides substrate chemistry, plant species may alter decomposition rates through their effects on the physical environment or the soil community, particularly if they form monospecific patches (Eviner and Chapin 2003). For example, species effects on microclimate can have significant consequences for biogeochemistry (Mack and D'Antonio 2003). A number of experiments have used reciprocal litter transplants to compare substrate vs. environmental effects on decomposition across environmental gradients (Vitousek et al. 1994, Austin and Vitousek 2000, Hobbie and Vitousek 2000, Pouyat and Carreiro 2003). However, experiments that examine environmental effects on decomposition caused by species are more rare.

We used a common garden experiment of 14 tree species in southwestern Poland to explore species effects on leaf litter decomposition and $\mathrm{N}$ dynamics. Our specific objectives were to (1) compare species effects on decomposition via litter chemistry vs. the environment and (2) to determine whether the lignin- $\mathrm{N}$ paradigm of decomposition control holds true across diverse deciduous and evergreen, angiosperm and gymnosperm trees. Because earthworms are present at this site, we also determined whether the same litter chemistry characteristics explain species differences in leaf litter dynamics when earthworms are excluded from litter vs. when litter is accessible to earthworms.

\section{Materials And Methods}

\section{Site description}

We studied a common garden experiment of 14 European and North American tree species at the Siemianice Experimental Forest near Biadaszki, Poland $\left(51^{\circ} 14.87^{\prime} \mathrm{N}, 18^{\circ} 06.35^{\prime} \mathrm{E}\right.$, elevation $150 \mathrm{~m}$ ) (Reich et al. 2005). In 1970-1971, $20 \times 20 \mathrm{~m}$ monospecific plots were established of Scots pine (Pinus sylvestris L.), silver birch (Betula pendula Roth.), European hornbeam (Carpinus betulus L.), Austrian black pine (Pinus nigra Arn.), red oak (Quercus rubra L.), silver fir (Abies alba Mill.), European beech (Fagus sylvatica L.), sycamore (Acer pseudoplatanus L.), Norway maple (Acer platanoides L.), small leafed lime (Tilia cordata Mill.), Norway spruce (Picea abies [L.] Karst.), European larch (Larix decidua Mill.), Douglas fir (Pseudotsuga menziesii Franco), and English oak (Quercus robur L.). Plots were set up in two blocks (nine species per block, three replicates per species) with four species (Picea, Larix, Pseudotsuga, and $Q$. robur) grown in both blocks.

The site was prepared by clear-cutting an 81-year-old $P$. sylvestris stand followed by stump removal and soil plowing (up to a depth of $60 \mathrm{~cm}$ ). Seedlings for the experiment were obtained from the Pelplin nursery $\left(53^{\circ} 55^{\prime} \mathrm{N}, 18^{\circ} 41^{\prime} \mathrm{E}\right.$, elevation $\left.55 \mathrm{~m}\right)$ except $P$. nigra, which was obtained from the Kraszkowice nursery $\left(51^{\circ} 12^{\prime} \mathrm{N}, 18^{\circ} 43^{\prime} \mathrm{E}\right.$, elevation $\left.171 \mathrm{~m}\right)$. (The Pelplin and Kraszkowice nurseries are part of the Polish State Forest system.) In the spring of 1970, one-year-old seedlings of nine species (Betula, P. nigra, P. sylvestris,
Q. rubra, Carpinus, Picea, Larix, Pseudotsuga, Q. robur) were planted in one of the blocks (399 seedlings per plot). In the following year, two-year-old seedlings of nine species (A. pseudoplatanus, A. platanoides, Fagus, Tilia, Q. robur, Pseudotsuga, Larix, Abies, Picea) originating from the same seed lots were planted in the adjacent block. Therefore, trees at both sites were of the same age. Because of poor survival of Abies seedlings, only two replicate plots survived.

The climate of the region is transitional between maritime and continental. Mean annual precipitation is $591 \mathrm{~mm}$, of which half falls from May to August, and mean annual temperature is $8.2^{\circ} \mathrm{C}$. Soils at the site formed on sandy outwash overlying finer textured glacial deposits. Before establishment of the common garden, the soil $\mathrm{pH}$ of the $\mathrm{A}$ horizon averaged 4.3. However, since plot establishment, soil pH, exchangeable base cations, and earthworm abundances have diverged among species, with $A$. platanoides, A. pseudoplatanus, and Tilia plots having the most basic soils with the highest exchangeable $\mathrm{Ca}$ concentrations and earthworm abundances, and $P$. sylvestris, $P$. nigra, and Larix plots having the most acidic soils with low exchangeable base cation concentrations and earthworm abundances (Reich et al. 2005).

\section{Litter decomposition experiments}

We established three simultaneous leaf-litter decomposition experiments using litter bags. In the first experiment (hereafter, "Home Plot"), we determined the combined effects of different species on decomposition via their influence on the environment for decomposition and on substrate chemistry by decomposing each plot's litter in situ. In the second (hereafter, "Common Plot"), we isolated tree species effects on decomposition via their influence on substrate chemistry by decomposing litter from all plots in a common plot (one A. pseudoplatanus plot). In the third (hereafter, "Common Substrate"), we isolated the influence of tree species on the decomposition environment by decomposing a common leaf litter (A. pseudoplatanus) in all of the plots.

Litter for litter bags was obtained from collections of total fine litterfall made monthly from 31 May 1996 through 30 November 1998 using litter traps $\left(0.38-\mathrm{m}^{2}\right.$ traps, eight traps per plot). Litter was dried $\left(65^{\circ} \mathrm{C}\right)$ and leaf litter of the dominant species in the plot was separated and pooled across collection dates for use in litter bags. For the Common Substrate experiment, litter from all plots of $A$. pseudoplatanus was pooled across collections. Litter bags were constructed from nylon tent netting (0.3-mm mesh) and bags were filled with $5 \mathrm{~g}$ (Home and Common Plots) or $2.3 \mathrm{~g}$ (Common Substrate) of litter. A small mesh was used because of the large number of needle-leaved species in the experiment. We constructed sufficient bags for two bags per plot and five harvests for the Home Plot and Common 
Substrate experiments, and one bag per plot and five harvests for the Common Plot experiment.

Subsamples of initial litter from each plot were ground and analyzed for (1) carbon fractions (Van Soest 1994) on an ANKOM Fiber Analyzer (Ankom Technology, Macedon, NY, USA) (cell solubles, hemicellulose and bound protein, cellulose, and lignin and other recalcitrants, determined on an ash-free dry mass basis); (2) phosphorus, calcium, potassium, and magnesium by ICP (Applied Research Laboratory 3560, ThermoElectron, Waltham, Massachusetts, USA) following digestion in $10 \% \mathrm{HCl}$ (Munter and Grande 1981) at the University of Minnesota's Research Analytical Laboratory, St. Paul, Minnesota, USA; and (3) carbon and nitrogen on a Costech ECS4010 Element Analyzer (Costech Analytical, Valencia, California, USA) at the University of Nebraska at Lincoln, Nebraska, USA. Initial litter $\mathrm{N}$ and $\mathrm{C}$ fractions (on a total mass basis) have been previously reported (Reich et al. 2005).

We placed litter bags in the field on 30 November 2002 and harvested subsets on 14 May, 24 July, and 10 October 2003, then on 14 June and 5 October 2004. Upon harvest, litter was removed from bags, separated from roots and the like, dried $\left(65^{\circ} \mathrm{C}\right)$, and weighed. The proportion of initial mass was calculated by dividing the mass at any harvest date by the initial mass. In addition, we determined decay constants $(k)$ by fitting the data for each plot with a negative exponential decay model (using linear regressions of $\mathrm{ln}$-transformed proportions of initial mass remaining against time). Harvested litter was ground and analyzed for $\mathrm{N}$. The proportion of initial $\mathrm{N}$ at each harvest date was calculated by multiplying percentage of $\mathrm{N}$ by litter mass and comparing it to the initial litter $\mathrm{N}$ pool.

We compared decomposition rates to environmental parameters measured in this study or reported in Reich et al. (2005). Soil temperatures were measured (at a 10 $\mathrm{cm}$ depth) using one datalogger centered in each plot (HOBO 8K, Onset Computer Corporation, Bourne, Massachusetts, USA). Temperatures were recorded each hour between February 1999 and November 2000. We also compared decomposition rates to $\mathrm{O}$ horizon soil $\mathrm{pH}$ (water) and $\mathrm{O}$ horizon mass (Reich et al. 2005), presumably a surrogate for $\mathrm{O}$ horizon moisture content.

Earthworms (whose biomass is dominated by Lumbricus terrestris) are present in the Siemianice site (Reich et al. 2005; C. M. Hale, unpublished data), but were excluded from our litter bags (i.e., we never observed earthworms in the bags upon harvest). Therefore, our experiments measured decomposition resulting exclusively from microbial and microfaunal activity. To determine whether the same litter chemistry characteristics that explain species differences in leaf litter decomposition when litter is contained in litter bags (i.e., earthworms excluded) also explain differences in forest floor dynamics when litter is accessible to earthworms, we compared the results from the Home Plot experiment with estimates of forest floor dynamics obtained under steady state assumptions (i.e., that litterfall inputs to the forest floor equal litterfall outputs via decomposition/removal) using measurements of annual litterfall and forest floor mass data presented in Reich et al. (2005). Litterfall inputs to the forest floor have likely been relatively constant for over two decades, since the dense planting in these stands resulted in canopy closure after 10 years (Szymanski 1982) and six years of litterfall data collected between 1996 and 2004 show no significant temporal trend (J. Oleksyn, unpublished data); thus, the litterfall data used in our calculations (collected in 1996-1997, Reich et al. 2005) should be representative of steady state litterfall. Sensu Olson (1963), we calculated forest floor decay rates $\left(k_{1}\right)$ assuming continuous litterfall mass $(L)$ where $F$ is forest floor mass (i.e., $\mathrm{O}_{\mathrm{e}}+\mathrm{O}_{\mathrm{i}}+\mathrm{O}_{\mathrm{a}}$ horizon mass; Reich et al. [2005]):

$$
k_{1}=L / F \text {. }
$$

Since litterfall is relatively discrete in this temperate system, particularly for the deciduous taxa, we also calculated decay rates $\left(k_{2}\right)$ using Olson's equation for discrete autumn litterfall, where $T$ is the maximum forest floor mass, approximated as late-summer (August; Reich et al. 2005) forest floor mass plus litterfall mass $(T=F+L)$ :

$$
k_{2}=-\ln (1-L / T) .
$$

We recognize that these decay rates might more accurately be termed forest floor "removal rates," since the fate of lost litter could be its translocation to deeper soil horizons by soil organisms and hereafter we refer to these removal rates as such. We further recognize that actual forest floor removal rates are likely an intermediate between $k_{1}$ and $k_{2}$ for the evergreen taxa, and closer to $k_{2}$ for the deciduous taxa. Therefore, we present both.

Plowing prior to planting likely eliminated the preexisting Pinus sylvestris forest floor. Thus, the forest floor dynamics estimated here should reflect those of the current canopy species. Our steady state assumption is reasonable for the more rapidly decomposing species, but may have caused us to overestimate removal rates of more slowly decomposing species: after 31 years (the stand age at which forest floor mass was sampled; Reich et al. 2005), forest floor mass should have reached steady state for species with $k_{1}>0.17$ (given that $F / F_{\mathrm{ss}}=1-$ $\mathrm{e}^{-k t}$, where $F_{\mathrm{ss}}$ is steady state forest floor mass and $t$ is stand age; Olson 1963). However, even for a species with $k_{1}$ as slow as 0.05 , forest floor mass would have been at $79 \%$ of its steady state value in a 31 yr-old stand.

\section{Analyses}

Initial $t$ test comparisons between the two blocks for mass remaining at the final harvest and decay rates for those species present in both blocks indicated no statistically significant differences between blocks $(P>$ $0.05)$. Therefore, in all subsequent analyses, we ignored 
blocking. Because we were primarily interested in species-level effects on decomposition (rather than within-species variation), we analyzed the data using species means.

We used stepwise multiple regression with backwards elimination to determine which factors explained significant variation among species in decomposition, after screening potential independent variables for significant autocorrelation $(r>0.80)$. For the Home Plot experiment, we considered all initial litter chemistry variables, mean annual soil temperature $\left(\mathrm{MAT}_{\text {soil }}\right), \mathrm{O}$ horizon $\mathrm{pH}$, and $\mathrm{O}$ horizon mass for the initial model. For the Common Plot experiment, we considered only initial litter chemistry variables, and for the Common Substrate experiment, we considered only $\mathrm{MAT}_{\text {soil }}, \mathrm{O}$ horizon $\mathrm{pH}$, and $\mathrm{O}$ horizon mass in the initial model. We conducted analyses using decay constants determined by assuming negative exponential decay as the independent variable. Because the error associated with fitting the regression models used to obtain decay constants is not accounted for when using decay constants as independent variables in subsequent analyses, we confirmed the results of these analyses using the proportion of initial mass remaining after the final harvest (averaging the two litter bags per plot per harvest).

We calculated the maximum amount of $\mathrm{N}$ immobilized into decomposing litter (milligrams of $\mathrm{N}$ per gram of initial litter mass) by identifying the harvest date at which the proportion of initial $\mathrm{N}$ was at its maximum. We then multiplied the maximum proportion of initial $\mathrm{N}$ during the experiment by the initial litter $\mathrm{N}$ content, subtracted the initial $\mathrm{N}$ content, and normalized by initial litter mass. If litter $\mathrm{N}$ declined from the initial content during the experiment, we scored immobilization for that plot as zero. We compared the maximum $\mathrm{N}$-immobilization among plots and species in the Home and Common Plot experiments to litter chemistry using backwards stepwise regression.

\section{RESUlTS}

\section{Litter bag experiments}

Negative exponential decay models generally described the litter bag data well. For the Home Plot experiment, all regressions were significant $(P<0.03)$ and the fits were generally good $\left(R^{2}\right.$ mean $=0.83$, median $=0.86$, range $0.49-0.97$ ). For the Common Substrate experiment, all regressions were also significant $(P \leq 0.05)$ and the fits were also good $\left(R^{2}\right.$ mean $=$ 0.84 , median $=0.85$, range $0.55-0.98$ ). For the Common Plot experiment, the significance of the regressions was lower, since there was only one (as opposed to two) litter bag per plot per harvest to use in developing regressions (mean $P=0.02$, median $P=0.01$, maximum $P=0.14$ ) and the fits were good $\left(R^{2}\right.$ mean $=0.90$, median $=0.92$, range 0.57-1.00).

After two years, there were significant differences among species in decomposition in the Home Plot experiment (one-way ANOVA, $P=0.01$ ), with $P$. sylvestris, Quercus rubra, Carpinus, Acer spp., and Betula having the most rapid decay rates, and Larix, Abies, and Fagus having the slowest decay rates (Fig. 1, Table 1). In stepwise regression analysis, litter lignin (Table 2 ) was significantly negatively related $(P=0.03$, Table 3), while $\mathrm{MAT}_{\text {soil }}$ was positively, albeit weakly, related to litter decay rates $(P=0.06$, Table 3$)$. Leaf litter $\mathrm{K}$, O horizon $\mathrm{pH}$, and forest floor mass were excluded from the analysis because of tight correlations with litter $\mathrm{Ca}(r=0.82,0.89$, and -0.80 , respectively; $P<0.001)$; litter cell-soluble content was excluded because of tight correlation with litter lignin $(r=-0.83, P<0.001)$; and litter $\mathrm{Mg}$ was excluded because of tight correlation with litter $\mathrm{P}(r=0.79, P<0.001)$. We obtained similar results analyzing mass remaining at the final harvest: lignin was negatively and $\mathrm{MAT}_{\text {soil }}$ was positively related to mass loss $\left(P=0.02\right.$ and $P=0.03$, respectively; $R^{2}=0.49$ ).

Decay rates in the Common and Home Plot experiments were significantly correlated (Fig. $1 ; r=0.61, P=$ 0.02 ), suggesting that much of the variation among species in decomposition of litter in situ arose from variation in substrate chemistry. In the Common Plot experiment, decay rates were negatively related to litter lignin and positively related to litter $\mathrm{Ca}(P=0.01$ and $P$ $=0.04$, respectively; Table 3 ). Similarly, mass loss at the final harvest was negatively related to litter lignin and positively related to litter Ca $(P=0.006$ and $P=0.03$, respectively; $R^{2}=0.63$ ).

By contrast, decay rates in the Common Substrate and Home Plot experiments were unrelated $(r=-0.15, P$ $=0.62$ ). In stepwise regression analysis, only $\mathrm{MAT}_{\text {soil }}$ was significantly (positively) related to decay rates of a common substrate across different species plots $(P=$ 0.02 , Table 3 ). Similarly, only MAT $_{\text {soil was significantly }}$ (positively) related to mass loss at the final harvest in the Common Substrate experiment $\left(P=0.008, R^{2}=0.46\right)$.

\section{Mass balance estimates}

In addition to measuring litter decomposition using litter bags, we estimated forest floor removal rates by mass balance. Values of $k_{1}$ (assuming continuous litterfall) and $k_{2}$ (assuming discrete autumn litterfall) were similar at the lower range, but $k_{1}$ exceeded $k_{2}$ at higher values (Table 1). Decay constants determined using litter bags (in the Home Plot experiment) were unrelated to $k_{1}$ or $k_{2}(P=0.22$ and 0.24 , Table 1$)$. Using the same statistical model used to analyze the Home Plot experiment (excluding forest floor mass, which was used to calculate removal rates), litter Ca alone was significant in explaining variation in $k_{1}$ among species, being positively related to removal rate $\left(P<0.0001, R^{2}=0.73\right)$. The difference between decay rates estimated using litter bags and $k_{1}$ was also significantly positively related to leaf litter $\mathrm{Ca}$, because at high litter $\mathrm{Ca}, k_{1}$ greatly exceeded litter bag decay rates, but at low litter $\mathrm{Ca}, k_{1}$ was less than litter bag decay rates (Fig. 2; $P<0.0001, R^{2}=0.72$ ). Litter Ca was highly significantly (positively) related to $k_{2}(P<0.0001) ; \mathrm{MAT}_{\text {soil }}$ was weakly (positively) related 


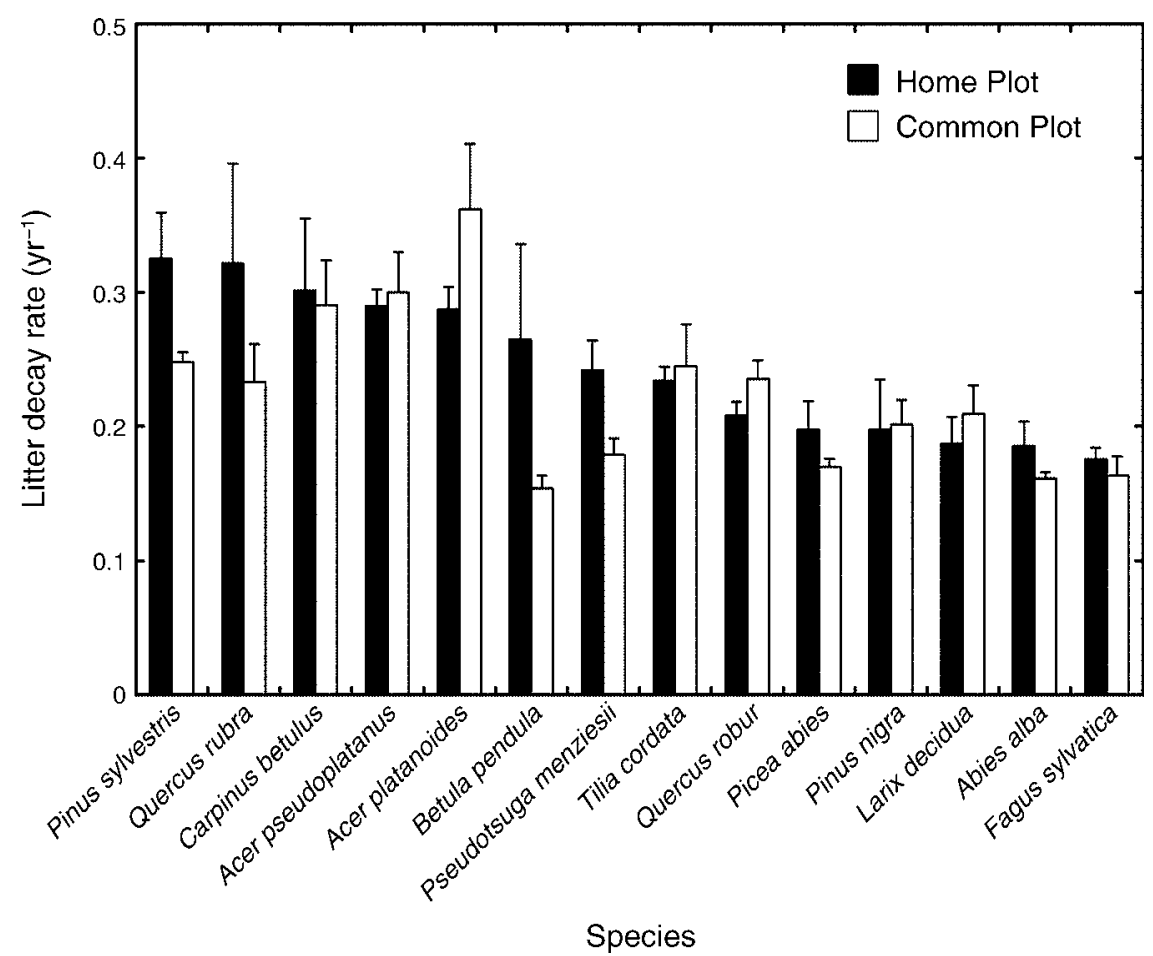

FIG. 1. Decay rate $($ mean $+\mathrm{SE})$ of litter of 14 species decomposed in its plot of origin (Home Plot experiment) or in a common site (Common Plot experiment). Species are ranked from the most rapidly to the most slowly decomposing in the Home Plot experiment.

$(P=0.05)$ while litter $\mathrm{N}$ was significantly negatively related to $k_{2}\left(P=0.01, R^{2}=0.88\right)$.

\section{Litter nitrogen dynamics}

Nearly all litter types in all experiments were still immobilizing $\mathrm{N}$ after two years (Appendix). Some species had approximately their original litter $\mathrm{N}$ content after two years (e.g., Betula, Carpinus, Q. robur, Tilia), while others were still exhibiting substantial immobilization (e.g., A. platanoides, Larix, Pinus spp., Pseudotsuga). The proportion of initial $\mathrm{N}$ (across all harvest dates and plots) was correlated between the Home and

TABLE 1. Litter bag decay constants $(k)$ in the three experiments, mass balance decay constants $\left(k_{1}\right.$ and $\left.k_{2}\right)$, and annual soil temperature (all values are mean $\pm \mathrm{SE}$ ).

\begin{tabular}{lccccccc}
\hline \hline & \multicolumn{2}{c}{$k$ from litter bag experiments $\left(\mathrm{yr}^{-1}\right)$} & & & \\
\cline { 2 - 5 } \multicolumn{1}{c}{ Species } & Home & Common & Common & & & \\
Plot & Plot & Substrate & & $k_{1} \dagger\left(\mathrm{yr}^{-1}\right)$ & & $k_{2}\left(\mathrm{yr}^{-1}\right)$ & $\begin{array}{c}\text { Annual soil } \\
\text { temperature }\left({ }^{\circ} \mathrm{C}\right)\end{array}$ \\
\hline Abies alba & $0.19 \pm 0.02$ & $0.16 \pm 0.00$ & $0.30 \pm 0.02$ & $0.06 \pm 0.00$ & $0.06 \pm 0.00$ & $9.89 \pm 0.14$ \\
Acer platanoides & $0.29 \pm 0.02$ & $0.36 \pm 0.05$ & $0.27 \pm 0.01$ & $1.09 \pm 0.29$ & $0.72 \pm 0.14$ & $10.17 \pm 0.26$ \\
Acer pseudoplatanus & $0.29 \pm 0.01$ & $0.30 \pm 0.03$ & $0.31 \pm 0.04$ & $0.88 \pm 0.38$ & $0.59 \pm 0.20$ & $10.42 \pm 0.12$ \\
Betula pendula & $0.26 \pm 0.07$ & $0.15 \pm 0.01$ & $0.35 \pm 0.03$ & $0.35 \pm 0.15$ & $0.28 \pm 0.11$ & $10.92 \pm 0.27$ \\
Carpinus betulus & $0.30 \pm 0.05$ & $0.29 \pm 0.03$ & $0.26 \pm 0.03$ & $0.05 \pm 0.00$ & $0.05 \pm 0.00$ & $10.08 \pm 0.11$ \\
Fagus sylvatica & $0.18 \pm 0.01$ & $0.16 \pm 0.01$ & $0.33 \pm 0.02$ & $0.23 \pm 0.10$ & $0.20 \pm 0.08$ & $10.13 \pm 0.11$ \\
Larix decidua & $0.19 \pm 0.02$ & $0.21 \pm 0.02$ & $0.34 \pm 0.03$ & $0.09 \pm 0.02$ & $0.08 \pm 0.01$ & $10.41 \pm 0.09$ \\
Picea abies & $0.20 \pm 0.02$ & $0.17 \pm 0.01$ & $0.27 \pm 0.02$ & $0.10 \pm 0.05$ & $0.09 \pm 0.04$ & $9.69 \pm 0.07$ \\
Pinus nigra & $0.20 \pm 0.04$ & $0.20 \pm 0.02$ & $0.28 \pm 0.03$ & $0.08 \pm 0.01$ & $0.08 \pm 0.01$ & $10.00 \pm 0.08$ \\
Pinus sylvestris & $0.33 \pm 0.03$ & $0.25 \pm 0.01$ & $0.31 \pm 0.01$ & $0.10 \pm 0.02$ & $0.09 \pm 0.02$ & $10.27 \pm 0.06$ \\
Pseudotsuga menziesii & $0.24 \pm 0.02$ & $0.18 \pm 0.01$ & $0.23 \pm 0.03$ & $0.07 \pm 0.01$ & $0.07 \pm 0.01$ & $9.86 \pm 0.05$ \\
Quercus robur & $0.21 \pm 0.01$ & $0.24 \pm 0.01$ & $0.34 \pm 0.04$ & $0.36 \pm 0.14$ & $0.29 \pm 0.10$ & $10.19 \pm 0.07$ \\
Quercus rubra & $0.32 \pm 0.07$ & $0.23 \pm 0.03$ & $0.31 \pm 0.02$ & $0.13 \pm 0.03$ & $0.12 \pm 0.03$ & $10.12 \pm 0.09$ \\
Tilia cordata & $0.23 \pm 0.01$ & $0.24 \pm 0.03$ & $0.34 \pm 0.06$ & $0.92 \pm 0.32$ & $0.62 \pm 0.17$ & $10.14 \pm 0.08$ \\
\hline
\end{tabular}

Notes: For mass balance estimates and mean annual soil temperature, "species" refers to the identity of the dominant species in the plot where measurements were made. For litter bag decay rates, "species" refers to the identity of the dominant species in the plot where litter was decomposed (Common Substrate), the identity of the species whose litter was decomposed (Common Plot), or both (Home Plot).

$\dagger$ From Reich et al. (2005). 
TABLE 2. Initial litter chemistry parameters (means with SE in parentheses) for 14 species grown in a common garden experiment.

\begin{tabular}{|c|c|c|c|c|c|c|c|c|c|c|c|}
\hline \multirow[b]{2}{*}{ Species } & \multirow[b]{2}{*}{$\mathrm{C}: \mathrm{N}$} & \multicolumn{5}{|c|}{$\begin{array}{l}\text { Initial litter nutrients } \\
\text { (mg element/g litter) }\end{array}$} & \multicolumn{4}{|c|}{$\begin{array}{l}\text { Initial litter } \mathrm{C} \text { fractions } \\
\text { (mg/g ash-free dry mass) }\end{array}$} & \multirow[b]{2}{*}{$\begin{array}{c}\text { Ash } \\
(\mathrm{mg} / \mathrm{g} \text { litter })\end{array}$} \\
\hline & & $\mathrm{N}$ & $\mathrm{Ca}$ & $\mathrm{K}$ & $\mathrm{Mg}$ & $\mathrm{P}$ & $\begin{array}{c}\text { Cell } \\
\text { solubles }\end{array}$ & Cellulose & $\begin{array}{l}\text { Hemi- } \\
\text { cellulose }\end{array}$ & Lignin & \\
\hline Abies alba & $\begin{array}{l}41.2 \\
(4.1)\end{array}$ & $\begin{array}{l}12.5 \\
(1.3)\end{array}$ & $\begin{array}{l}12.4 \\
(1.1)\end{array}$ & $\begin{array}{l}2.2 \\
(0.4)\end{array}$ & $\begin{array}{c}0.8 \\
(0.1)\end{array}$ & $\begin{array}{l}1.18 \\
(0.07)\end{array}$ & $\begin{array}{l}370.1 \\
(36.5)\end{array}$ & $\begin{array}{r}199.9 \\
(5.9)\end{array}$ & $\begin{array}{r}123.4 \\
(2.9)\end{array}$ & $\begin{array}{l}304.6 \\
(27.6)\end{array}$ & $\begin{array}{c}3.4 \\
(0.7)\end{array}$ \\
\hline Acer platanoides & $\begin{array}{l}68.9 \\
(4.8)\end{array}$ & $\begin{array}{l}6.5 \\
(0.4)\end{array}$ & $\begin{array}{l}19.0 \\
(1.7)\end{array}$ & $\begin{array}{l}6.6 \\
(0.9)\end{array}$ & $\begin{array}{l}1.6 \\
(0.1)\end{array}$ & $\begin{array}{l}1.29 \\
(0.05)\end{array}$ & $\begin{array}{l}530.6 \\
(30.5)\end{array}$ & $\begin{array}{l}180.2 \\
(14.3)\end{array}$ & $\begin{array}{r}160.8 \\
(9.8)\end{array}$ & $\begin{array}{r}125.9 \\
(6.2)\end{array}$ & $\begin{array}{l}16.1 \\
(4.6)\end{array}$ \\
\hline Acer pseudo-platanus & $\begin{array}{l}49.1 \\
(6.2)\end{array}$ & $\begin{array}{c}9.4 \\
(1.1)\end{array}$ & $\begin{array}{l}21.8 \\
(2.3)\end{array}$ & $\begin{array}{l}6.9 \\
(0.8)\end{array}$ & $\begin{array}{l}1.6 \\
(0.2)\end{array}$ & $\begin{array}{l}1.16 \\
(0.24)\end{array}$ & $\begin{array}{r}524.2 \\
(5.9)\end{array}$ & $\begin{array}{r}184.3 \\
(9.8)\end{array}$ & $\begin{array}{r}122.7 \\
(2.7)\end{array}$ & $\begin{array}{r}166.8 \\
(7.9)\end{array}$ & $\begin{array}{l}16.7 \\
(1.8)\end{array}$ \\
\hline Betula pendula & $\begin{array}{l}38.5 \\
(1.1)\end{array}$ & $\begin{array}{l}12.6 \\
(0.2)\end{array}$ & $\begin{array}{l}11.5 \\
(0.4)\end{array}$ & $\begin{array}{l}3.2 \\
(0.6)\end{array}$ & $\begin{array}{l}2.4 \\
(0.1)\end{array}$ & $\begin{array}{l}1.61 \\
(0.02)\end{array}$ & $\begin{array}{l}278.0 \\
(31.9)\end{array}$ & $\begin{array}{r}186.8 \\
(1.9)\end{array}$ & $\begin{array}{r}124.4 \\
(6.2)\end{array}$ & $\begin{array}{l}408.7 \\
(39.7)\end{array}$ & $\begin{array}{c}57.1 \\
(22.0)\end{array}$ \\
\hline Carpinus betulus & $\begin{array}{l}42.7 \\
(2.0)\end{array}$ & $\begin{array}{l}11.0 \\
(0.5)\end{array}$ & $\begin{array}{l}9.2 \\
(0.5)\end{array}$ & $\begin{array}{c}3.9 \\
(0.8)\end{array}$ & $\begin{array}{l}1.5 \\
(0.1)\end{array}$ & $\begin{array}{c}1.85 \\
(0.05)\end{array}$ & $\begin{array}{c}496.2 \\
(20.1)\end{array}$ & $\begin{array}{r}200.8 \\
(6.8)\end{array}$ & $\begin{array}{c}155.3 \\
(5.1)\end{array}$ & $\begin{array}{l}143.6 \\
(16.0)\end{array}$ & $\begin{array}{c}26.8 \\
(2.9)\end{array}$ \\
\hline Fagus sylvatica & $\begin{array}{l}55.9 \\
(3.6)\end{array}$ & $\begin{array}{c}8.4 \\
(0.5)\end{array}$ & $\begin{array}{c}12.9 \\
(0.5)\end{array}$ & $\begin{array}{c}4.2 \\
(1.0)\end{array}$ & $\begin{array}{l}1.1 \\
(0.1)\end{array}$ & $\begin{array}{c}1.41 \\
(0.15)\end{array}$ & $\begin{array}{l}381.5 \\
(26.3)\end{array}$ & $\begin{array}{c}231.9 \\
(12.9)\end{array}$ & $\begin{array}{c}138.8 \\
(8.1)\end{array}$ & $\begin{array}{c}245.7 \\
(18.9)\end{array}$ & $\begin{array}{l}13.2 \\
(3.3)\end{array}$ \\
\hline Larix decidua & $\begin{array}{c}64.9 \\
(10.1)\end{array}$ & $\begin{array}{c}8.7 \\
(1.3)\end{array}$ & $\begin{array}{c}6.9 \\
(0.7)\end{array}$ & $\begin{array}{c}1.5 \\
(0.3)\end{array}$ & $\begin{array}{c}1.4 \\
(0.1)\end{array}$ & $\begin{array}{c}1.39 \\
(0.11)\end{array}$ & $\begin{array}{l}365.5 \\
(21.3)\end{array}$ & $\begin{array}{r}222.0 \\
(9.3)\end{array}$ & $\begin{array}{c}92.6 \\
(5.1)\end{array}$ & $\begin{array}{c}317.4 \\
(18.0)\end{array}$ & $\begin{array}{c}3.7 \\
(0.8)\end{array}$ \\
\hline Picea abies & $\begin{array}{c}49.3 \\
(2.5)\end{array}$ & $\begin{array}{c}9.9 \\
(0.4)\end{array}$ & $\begin{array}{l}11.1 \\
(0.5)\end{array}$ & $\begin{array}{c}3.4 \\
(0.2)\end{array}$ & $\begin{array}{c}0.8 \\
(0.0)\end{array}$ & $\begin{array}{l}1.10 \\
(0.12)\end{array}$ & $\begin{array}{c}414.6 \\
(15.6)\end{array}$ & $\begin{array}{c}231.3 \\
(12.3)\end{array}$ & $\begin{array}{c}138.1 \\
(2.4)\end{array}$ & $\begin{array}{c}214.1 \\
(6.0)\end{array}$ & $\begin{array}{c}4.8 \\
(1.3)\end{array}$ \\
\hline Pinus nigra & $\begin{array}{c}98.7 \\
(13.9)\end{array}$ & $\begin{array}{c}5.4 \\
(0.9)\end{array}$ & $\begin{array}{c}3.1 \\
(0.5)\end{array}$ & $\begin{array}{c}2.3 \\
(0.1)\end{array}$ & $\begin{array}{c}0.5 \\
(0.1)\end{array}$ & $\begin{array}{c}0.51 \\
(0.09)\end{array}$ & $\begin{array}{c}289.7 \\
(7.2)\end{array}$ & $\begin{array}{r}316.0 \\
(3.3)\end{array}$ & $\begin{array}{r}153.8 \\
(6.6)\end{array}$ & $\begin{array}{c}238.7 \\
(11.3)\end{array}$ & $\begin{array}{c}2.9 \\
(0.4)\end{array}$ \\
\hline Pinus sylvestris & $\begin{array}{c}81.9 \\
(15.9)\end{array}$ & $\begin{array}{c}6.8 \\
(1.4)\end{array}$ & $\begin{array}{c}5.4 \\
(0.5)\end{array}$ & $\begin{array}{l}2.0 \\
(0.2)\end{array}$ & $\begin{array}{c}0.5 \\
(0.0)\end{array}$ & $\begin{array}{c}0.62 \\
(0.13)\end{array}$ & $\begin{array}{c}389.3 \\
(7.1)\end{array}$ & $\begin{array}{r}298.8 \\
(7.2)\end{array}$ & $\begin{array}{r}133.2 \\
(5.6)\end{array}$ & $\begin{array}{r}176.6 \\
(7.2)\end{array}$ & $\begin{array}{c}2.6 \\
(0.4)\end{array}$ \\
\hline Pseudotsuga menziesii & $\begin{array}{c}72.0 \\
(3.0)\end{array}$ & $\begin{array}{c}7.2 \\
(0.3)\end{array}$ & $\begin{array}{c}9.1 \\
(0.7)\end{array}$ & $\begin{array}{c}2.9 \\
(0.2)\end{array}$ & $\begin{array}{c}1.1 \\
(0.0)\end{array}$ & $\begin{array}{c}1.15 \\
(0.11)\end{array}$ & $\begin{array}{c}455.6 \\
(9.0)\end{array}$ & $\begin{array}{r}182.2 \\
(5.3)\end{array}$ & $\begin{array}{c}112.3 \\
(3.3)\end{array}$ & $\begin{array}{r}247.6 \\
(6.6)\end{array}$ & $\begin{array}{c}4.7 \\
(0.7)\end{array}$ \\
\hline Quercus robur & $\begin{array}{l}37.7 \\
(5.1)\end{array}$ & $\begin{array}{l}12.7 \\
(0.6)\end{array}$ & $\begin{array}{l}12.0 \\
(0.5)\end{array}$ & $\begin{array}{c}5.0 \\
(0.7)\end{array}$ & $\begin{array}{l}1.8 \\
(0.1)\end{array}$ & $\begin{array}{c}1.70 \\
(0.09)\end{array}$ & $\begin{array}{c}388.5 \\
(13.0)\end{array}$ & $\begin{array}{c}222.3 \\
(6.2)\end{array}$ & $\begin{array}{r}153.7 \\
(5.6)\end{array}$ & $\begin{array}{c}233.5 \\
(15.0)\end{array}$ & $\begin{array}{l}14.4 \\
(2.4)\end{array}$ \\
\hline Quercus rubra & $\begin{array}{l}68.7 \\
(5.5)\end{array}$ & $\begin{array}{c}7.1 \\
(0.5)\end{array}$ & $\begin{array}{l}11.8 \\
(0.6)\end{array}$ & $\begin{array}{c}3.1 \\
(0.6)\end{array}$ & $\begin{array}{c}1.4 \\
(0.1)\end{array}$ & $\begin{array}{c}1.38 \\
(0.05)\end{array}$ & $\begin{array}{r}417.8 \\
(6.4)\end{array}$ & $\begin{array}{r}232.2 \\
(1.6)\end{array}$ & $\begin{array}{r}149.6 \\
(3.2)\end{array}$ & $\begin{array}{r}198.4 \\
(1.0)\end{array}$ & $\begin{array}{c}9.5 \\
(1.2)\end{array}$ \\
\hline Tilia cordata & $\begin{array}{l}37.0 \\
(1.3)\end{array}$ & $\begin{array}{l}12.2 \\
(0.1)\end{array}$ & $\begin{array}{c}18.8 \\
(0.8)\end{array}$ & $\begin{array}{c}4.0 \\
(1.1)\end{array}$ & $\begin{array}{l}1.8 \\
(0.0)\end{array}$ & $\begin{array}{c}1.47 \\
(0.08)\end{array}$ & $\begin{array}{l}270.9 \\
(46.4)\end{array}$ & $\begin{array}{l}193.6 \\
(11.3)\end{array}$ & $\begin{array}{c}115.5 \\
(4.1)\end{array}$ & $\begin{array}{c}417.1 \\
(41.0)\end{array}$ & $\begin{array}{c}94.0 \\
(31.1)\end{array}$ \\
\hline Mean & 57.6 & 9.3 & 11.8 & 3.7 & 1.3 & 1.27 & 398.0 & 220.2 & 133.9 & 245.5 & 19.3 \\
\hline
\end{tabular}

Common Plot experiments $(r=0.63, P<0.0001)$, but not between the Common Substrate and the other experiments $(P>0.10$ in both cases). The maximum Nimmobilization (milligrams of $\mathrm{N}$ per gram of initial litter; data not shown) was significantly positively related to initial litter $\mathrm{C}: \mathrm{N}(P<0.0001)$ and $\mathrm{P}(P=$

TABLE 3. Results of stepwise multiple regressions with backwards elimination $(P>0.10)$ for decay rates after two years in the three litter bag experiments.

\begin{tabular}{lccc}
\hline \hline & \multicolumn{3}{c}{ Experiment } \\
\cline { 2 - 4 } \multicolumn{1}{c}{ Independent variable } & $\begin{array}{c}\text { Home } \\
\text { Plot }\end{array}$ & $\begin{array}{c}\text { Common } \\
\text { Plot }\end{array}$ & $\begin{array}{c}\text { Common } \\
\text { Substrate }\end{array}$ \\
\hline $\mathrm{N}(\%)$ & & & $\ldots$ \\
Cellulose (\%) & & & $\ldots$ \\
Hemicellulose (\%) & $(-)^{*}$ & $(-)^{*}$ & $\ldots$ \\
Lignin (\%) & & $(+)^{*}$ & $\ldots$ \\
Ca (\%) & $\mathrm{X}$ & $\ldots$ & $\ldots$ \\
$\mathrm{P}(\%)$ & $(+) \dagger$ & $\ldots$ & $(+)^{*}$ \\
Forest floor mass & 0.43 & 0.56 & 0.39 \\
$R^{2}$ & &
\end{tabular}

Notes: Ellipses indicate that a variable was excluded from the original model because of irrelevance. An " $X$ " indicates that a variable was excluded from the original model because of tight correlation with another variable in the model. Blank cells indicate nonsignificance $(P>0.10)$. The sign of the relationship between significant independent variables and decay rate $(-$ or $+)$ is indicated.

$* P<0.05 ; \dagger P<0.10$.
0.02) in the Home Plot experiment when all plots were included in the analysis $\left(R^{2}=0.30\right)$, but when species means were analyzed, $\mathrm{N}$-immobilization was unexplained by any litter chemistry parameters. In the Common Plot experiment, the maximum $\mathrm{N}$-immobilization was positively related to initial litter $\mathrm{C}: \mathrm{N}, \mathrm{Ca}$, and $\mathrm{P}$, when all plots were included in the analysis $(P<$ $0.001, P<0.001, P=0.01$, respectively; $\left.R^{2}=0.41\right)$, and to litter $\mathrm{C}: \mathrm{N}$ and $\mathrm{Ca}$ when species means were analyzed $\left(P=0.009, P=0.01\right.$, respectively; $\left.R^{2}=0.57\right)$.

\section{Discussion}

Taken together, the three experiments indicate that the 14 tree species studied here influence microbiallymediated decomposition, primarily through variation in litter lignin (and perhaps litter $\mathrm{Ca}$ ) and by influencing forest floor temperatures. Species with relatively low litter lignin (P. sylvestris, Acer spp., Carpinus, Q. rubra) generally exhibited the most rapid decomposition in both the Home and Common Plot experiments. Since litter lignin and litter cell solubles were so tightly correlated, we cannot rule out the possibility that more rapid decomposition of species with lignin-poor litter was caused by high concentrations of cell solubles. Litter Ca was significant in explaining species differences in litter decomposition in the Common Plot, but not the Home Plot, experiment. Inconsistent results between the two experiments could have arisen for two reasons. First, 
there may be litter-type-by-environment interactions that we were unable to assess using our experimental design because we decomposed all litter types in a single common environment (an A. pseudoplatanus plot). For example, a high $\mathrm{Ca}$ requirement of the microbial community in that plot compared to the average of other plots could have given the results we observed. Alternatively, variation among plots in environmental factors could have masked (statistically) a biologically significant relationship between litter $\mathrm{Ca}$ and decomposition across species in the Home Plot experiment. We cannot distinguish between these two alternatives given our experimental design. Species with high light penetration to the forest floor had warmer $\mathrm{MAT}_{\text {soil }}$ and relatively rapid decomposition in both the Home Plot and Common Substrate experiments MAT $_{\text {soil }}$ was significantly correlated with average growing-season PAR (photosynthetically active radiation) at a height of one meter; $r=0.78, P=0.001 ; \mathrm{J}$. Modrzynski, unpublished data). Species with little light penetration to the forest floor (e.g., Abies and Picea) had colder soil temperatures and slower decomposition. Although numerous studies have demonstrated relationships between lignin and decomposition (Hobbie 2000) and between temperature and decomposition across sites (Aerts 1997, Gholz et al. 2000), we are unaware of other studies demonstrating that monospecific tree stands significantly affect decomposition via both litter chemistry and effects on soil temperatures.

Plot differences in microbial $\mathrm{N}$-immobilization resulted from differences in litter chemistry, since immobilization patterns were correlated between the Home and Common Plot experiments, but not between the Common Substrate and the other experiments. Specifically, differences within and among species in litter $\mathrm{N}$ led to differences in $\mathrm{N}$-immobilization, with high $\mathrm{C}: \mathrm{N}$ litter increasing $\mathrm{N}$-immobilization over two years, likely because of greater $\mathrm{N}$ demand by microbes decomposing litter with relatively lower $\mathrm{N}$ content. Additionally, high litter $\mathrm{Ca}$ and/or $\mathrm{P}$ promoted $\mathrm{N}$-immobilization, perhaps because decomposers had a higher $\mathrm{N}$ demand, when they were supplied with adequate amounts of these other nutrients. Thus, while litter lignin was important in explaining variation in microbial decomposition rates among species, litter nutrient concentrations $(\mathrm{C}: \mathrm{N}$ ratio, $\mathrm{Ca}$, and $\mathrm{P}$ ) were important in explaining variation in litter $\mathrm{N}$ dynamics. Some unknown environmental differences among plots may have also contributed to variation in litter $\mathrm{N}$ dynamics, since the common substrate, A. pseudoplatanus, showed different patterns of immobilization depending on its plot of decomposition.

The match between decomposition assessed using litter bags and forest floor removal estimated by mass balance was extremely poor. The removal rates calculated by mass balance for many litter types were slower than were decay rates calculated from litter bags. This discrepancy is not surprising given that decomposition

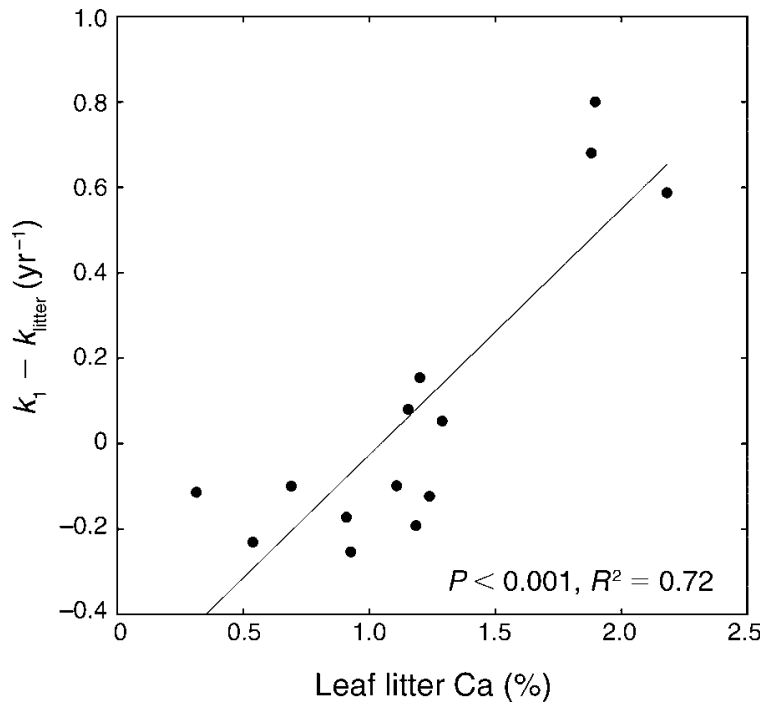

FIG. 2. The difference between decay rates obtained using litter bags in the Home Plot experiment $\left(k_{\text {litter }}\right)$ and $k_{1}$, estimated by mass balance as a function of leaf litter $\mathrm{Ca}$. Each point represents the mean of replicate plots for one of 14 tree species.

in litter bags was measured for only two years, by which point litter had lost only $29-48 \%$ of the initial mass. Presumably, if left to decompose longer, decay rates would have slowed as the relative amount of recalcitrant material in the litter increased. Mass balance estimates, by contrast, include the $\mathrm{O}_{\mathrm{a}}$ horizon that has begun to humify and is likely decaying at a slower rate than fresh litter.

More surprising were those species that exhibited faster decomposition estimated by mass balance. In particular, mass balance removal rates for $A$. platanoides, A. pseudoplatanus, and Tilia were two to three times faster than litter bag estimates of decay constants. What accounts for this large discrepancy? We believe that it is a straightforward consequence of the fact that litter uncontained by litter bags was accessible to earthworms, and that earthworms were responding more to species differences in litter $\mathrm{Ca}$ rather than to differences in litter lignin (or any other aspect of litter chemistry). Specifically, high litter $\mathrm{Ca}$ concentrations in Tilia and Acer spp. promoted high earthworm abundances that in turn led to rapid forest floor consumption and thus rapid apparent "decay" rates calculated by mass balance (Reich et al. 2005). However, when earthworms were excluded from litter (i.e., by litter bags), species with Ca-rich litter exhibited decomposition rates more in line with those expected, based on their lignin concentrations.

Numerous studies have demonstrated that earthworms enhance leaf litter or forest floor disappearance (Swift et al. 1979, Staaf 1987, Alban and Berry 1994, Liu and Zou 2002, Bohlen et al. 2004b, Hale et al. 2005). However, to our knowledge, few studies have linked variation in litter $\mathrm{Ca}$ concentrations to variation in the 
processing of litter by earthworms. Past studies have related earthworm abundance to soil $\mathrm{pH}$ and base cations (Piearce 1972a, Muys and Lust 1992, Robinson et al. 1992, Ponge et al. 1999, Curry 2004); however, studies of litter selection by earthworms have largely focused on litter N (Hendriksen 1990, Bohlen et al. 1997, Curry 2004).

Nevertheless, several lines of evidence support our interpretation that litter $\mathrm{Ca}$ drove plant species effects on earthworm litter consumption, despite lignin control over microbial decomposition. Litter $\mathrm{Ca}$ was the sole significant predictor of $k_{1}$ and the most highly significant predictor of $k_{2}$. Because earthworm abundance was highly correlated with litter $\mathrm{Ca}(r=0.81, P<0.0001$; Reich et al. 2005), we could not use both litter Ca and earthworm abundance in a stepwise regression. However, when we replaced litter $\mathrm{Ca}$ with earthworm abundance in the stepwise regression model, then earthworm abundance became the sole significant predictor of forest floor removal rates $\left(P=0.007, R^{2}=\right.$ 0.47 and $P=0.01, R^{2}=0.41$ for $k_{1}$ and $k_{2}$, respectively). Hendricksen (1990) also found a preference for Tilia litter over other hardwoods, but explained the results based on variation in litter $\mathrm{N}$ and phenolics. Litter $\mathrm{Ca}$ was not measured in that study, and was likely quite high in Tilia. Similarly, in a North American field study, when earthworm communities that included Lumbricus terrestris were offered litter of Tilia americana, Acer saccharum, and Quercus rubra, litter of Tilia and Acer (the two Ca-rich litter types) disappeared rapidly, with complete disappearance of Tilia after one year, while Quercus showed little mass loss over the same time period (A. R. Holdsworth, P. B. Reich, and L. E. Frelich, unpublished data).

Whether earthworms in this site are responding directly to higher litter $\mathrm{Ca}$ or to the concomitant higher concentrations of soil Ca (Reich et al. 2005) is unknown (Ponge et al. 1999). Regardless, the positive relationship between forest floor removal and litter Ca likely arises from the nutritional requirements of the earthworms at the site. Although there are several species of earthworms in the Siemianice Experimental Forest (Reich et al. 2005), earthworm biomass is dominated by Lumbricus terrestris (C. M. Hale, unpublished data). Lumbricus is an anecic species that makes deep burrows, but consumes litter on the soil surface. Lumbricus has welldeveloped calciferous glands that produce calcium carbonate (Robertson 1936, Canti and Piearce 2003). It has been suggested that Lumbricus and other species with well-developed calciferous glands produce calcium carbonate to reduce their blood $\mathrm{CO}_{2}$ levels and regulate blood $\mathrm{pH}$ when faced with high soil $\mathrm{CO}_{2}$ levels, and thus they have a high Ca requirement (Crang et al. 1968, Robertson 1936, Piearce 1972b).

The decomposition rate of litter removed from the surface by Lumbricus is unknown. However, litter removed from the soil surface likely decays more rapidly than surface litter because of partial digestion, fragmen- tation, more favorable moisture conditions, and enhanced microbial activity after passage through the earthworm gut (Bohlen et al. 2004a).

Our results have important implications for the generality and applicability of the lignin- $\mathrm{N}$ paradigm of litter decomposition control. First, the paradigm may be most important in predicting species effects on decomposition in those ecosystems lacking abundant Ca-demanding earthworms or where microbial activity dominates litter processing. It is possible that many studies that have been influential in developing the lignin-N paradigm were earthworm-free or inhabited by earthworms without high $\mathrm{Ca}$ requirements, either for geographic reasons (McClaugherty and Berg 1987) or because they were conducted in ecosystems dominated by species like Scots pine (Pinus sylvestris), that seem to inhibit Lumbricus terrestris (Meentemeyer and Berg 1986). Second, the lignin-N paradigm may reflect, in part, the prevalent use of litter bags in decomposition studies (including our own). The effects of litter bags on earthworm activity are likely complex, depending on both mesh size and earthworm species identity and its feeding strategy. For example, we never observed earthworms in the litter bags in this study. However, in a Hawaiian study, the same small mesh size used here was ineffective at excluding earthworms (S. E. Hobbie, unpublished data). Some studies report access by earthworms to litter in bags with 1-2 mm mesh (Liu and Zou 2002, Pouyat and Carreiro 2003), while others used 1$\mathrm{mm}$ mesh to exclude earthworms (Staaf 1987). Clearly more research is needed to determine interactions between earthworm species, feeding strategy, litter bag mesh size, and litter chemistry. Finally, our results provide insights into ongoing invasions by European earthworms in parts of North America (Bohlen et al. 2004c), suggesting that preferences for Ca-rich litter by some earthworm species could explain the predominance of non-native earthworms in hardwood-dominated stands in northern forests (Hale et al. 2005).

In conclusion, our comparison of the effects of 14 tree species on leaf litter decomposition suggests that differences among species in litter lignin (and perhaps $\mathrm{Ca}$ ) and soil temperatures explain much of the variation in species effects on microbial decomposition rates. Differences within and among species in litter nutrients $(C: N$, $\mathrm{Ca}$, and $\mathrm{P}$ ) explain much of the variation in microbial immobilization of $\mathrm{N}$ into decomposing litter. However, differences among species in forest floor dynamics are overwhelmingly related to differences in leaf-litter $\mathrm{Ca}$ that are driven, in turn, by differences in the abundance of Lumbricus terrestris. Ca-rich species like Tilia and Acer spp. exhibited rapid forest floor removal related to high earthworm abundance, while species like Abies, Picea, and Pinus spp. exhibited accumulation of a substantial forest floor mass and are associated with low earthworm abundance. Thus, while litter lignin is important in explaining species effects on microbially mediated decomposition, differences among species in 
litter $\mathrm{Ca}$ appear most important in determining species effects on forest-floor leaf-litter dynamics among the 14 tree species in this system. The overall influence of these tree species on leaf-litter decomposition via effects on both microbial and faunal processing will only become clear when we can quantify the decay dynamics of litter that is translocated belowground by earthworms.

\section{ACKNOWLEDGMENTS}

This research was supported by the National Science Foundation (DEB 0128958) and by the State Committee for Scientific Research, Poland (PBZ-KBN-087/P04/2003). We are grateful to Ewa Turzanska and Andrzej Jagodzinski for field assistance, and to Jerzy Modrzynski for litter collection and soil temperature measurements.

\section{Literature Cited}

Aerts, R. 1997. Climate, leaf litter chemistry and leaf litter decomposition in terrestrial ecosystems: a triangular relationship. Oikos 79:439-449.

Alban, D. H., and E. C. Berry. 1994. Effects of earthworm invasion on morphology, carbon, and nitrogen of a forest soil. Applied Soil Ecology 1:243-249.

Austin, A. T., and P. M. Vitousek. 2000. Precipitation, decomposition, and litter decomposability of Metrosideros polymorpha on Hawai'i. Journal of Ecology 88:129-138.

Berendse, F. 1998. Effects of dominant plant species on soils during succession in nutrient-poor ecosystems. Biogeochemistry 42:73-88.

Berg, B., and G. Eckbom. 1983. Nitrogen-immobilization in decomposing needle litter at variable carbon : nitrogen ratios. Ecology 64:63-67.

Bohlen, P. J., R. W. Parmelee, and J. M. Blair. 2004a. Integrating the effects of earthworms on nutrient cycling across spatial and temporal scales. Pages 161-180 in C. A. Edwards, editor. Earthworm Ecology. CRC Press, Boca Raton, Florida, USA.

Bohlen, P. J., R. W. Parmelee, D. A. McCartney, and C. A. Edwards. 1997. Earthworm effects on carbon and nitrogen dynamics of surface litter in corn agroecosystems. Ecological Applications 7:1341-1349.

Bohlen, P. J., D. M. Pelletier, P. M. Groffman, T. J. Fahey, and M. C. Fisk. 2004b. Influence of earthworm invasion on redistribution and retention of soil carbon and nitrogen in northern temperate forests. Ecosystems 7:13-27.

Bohlen, P. J., S. Scheu, C. M. Hale, M. A. McLean, S. Migge, P. M. Groffman, and D. Parkinson. 2004c. Non-native invasive earthworms as agents of change in northern temperate forests. Frontiers in Ecology and the Environment 2:427-435.

Canti, M. G., and T. G. Piearce. 2003. Morphology and dynamics of calcium carbonate granules produced by different earthworm species. Pedobiologia 47:511-521.

Crang, M. G., R. C. Holsen, and J. B. Hitt. 1968. Calcite production in mitochondria of earthworm calciferous glands. BioScience 18:299.

Curry, J. P. 2004. Factors affecting the abundance of earthworms in soils. Pages 91-113 in C. A. Edwards, editor. Earthworm Ecology. CRC Press, Boca Raton, Florida, USA.

Eviner, V. T., and F. S. Chapin, III. 2003. Functional matrix: a conceptual framework for predicting multiple plant effects on ecosystem processes. Annual Review of Ecology and Systematics 34:455-485.

Gholz, H. L., D. A. Wedin, S. M. Smitherman, M. E. Harmon, and W. J. Parton. 2000. Long-term dynamics of pine and hardwood litter decomposition in contrasting environments: toward a global model of decomposition. Global Change Biology 6:751-765.
Hale, C. M., L. E. Frelich, and P. B. Reich. 2005. Exotic European earthworm invasion dynamics in Northern hardwood forests of Minnesota, USA. Ecological Applications 15:848-860.

Hendriksen, N. B. 1990. Leaf litter selection by detritivore and geophagous earthworms. Biology and Fertility of Soils 10: $17-21$.

Hobbie, S. E. 1992. Effects of plant species on nutrient cycling. Trends in Ecology and Evolution 7:336-339.

Hobbie, S. E. 1996. Temperature and plant species control over litter decomposition in Alaskan tundra. Ecological Monographs 66:503-522.

Hobbie, S. E. 2000. Interactions between lignin and nutrient availability during decomposition in Hawaiian montane forest. Ecosystems 3:484-494.

Hobbie, S. E., and P. M. Vitousek. 2000. Nutrient regulation of decomposition in Hawaiian montane forests: do the same nutrients limit production and decomposition? Ecology 81: $1867-1877$.

Liu, Z. G., and X. M. Zou. 2002. Exotic earthworms accelerate plant litter decomposition in a Puerto Rican pasture and a wet forest. Ecological Applications 12:1406-1417.

Mack, M. C., and C. M. D'Antonio. 2003. Exotic grasses alter controls over soil nitrogen dynamics in a Hawaiian woodland. Ecological Applications 13:154-166.

McClaugherty, C. A., and B. Berg. 1987. Cellulose, lignin and nitrogen concentrations as rate regulating factors in late stages of forest litter decomposition. Pedobiologia 30:101112.

Meentemeyer, V. 1978. Macroclimate and lignin control of litter decomposition rates. Ecology 59:465-472.

Meentemeyer, V., and B. Berg. 1986. Regional variation in rate of mass loss of Pinus sylvestris needle litter in Swedish pine forests as influenced by climate and litter quality. Scandinavian Journal of Forest Research 1:167-180.

Melillo, J. M., J. D. Aber, and J. F. Muratore. 1982. Nitrogen and lignin control of hardwood leaf litter decomposition dynamics. Ecology 63:621-626.

Moorehead, D. L., R. L. Sinsabaugh, A. E. Linkins, and J. F. Reynolds. 1996. Decomposition processes: modeling approaches and applications. Science for the Total Environment 183:137-149.

Munter, R. C., and R. A. Grande. 1981. Plant tissue and soil extract analysis by ICP-AES. Pages 653-673 in R. M. Barnes, editor. Developments in atomic plasma spectrochemical analysis. Heydon and Son, Philadelphia, Pennsylvania, USA.

Muys, B., and N. Lust. 1992. Inventory of earthworm communities and the state of litter decomposition in the forests of Flanders, Belgium, and its implications for forest management. Soil Biology and Biochemistry 24:1677-1681.

Olson, J. S. 1963. Energy storage and the balance of producers and decomposers in ecological systems. Ecology 44:322-331.

Pastor, J., M. A. Stillwell, and D. Tilman. 1987. Little bluestem litter dynamics in Minnesota old fields. Oecologia 72:327330.

Piearce, T. G. 1972a. Acid intolerant and ubiquitous Lumbricidae in selected habitats in North Wales. Journal of Animal Ecology 41:397-410.

Piearce, T. G. 1972b. The calcium relations of selected Lumbricidae. Journal of Animal Ecology 41:167-188.

Ponge, J.-F., N. Patzel, L. Delhaye, E. Devigne, C. Levieux, P. Beros, and R. Wittebroodt. 1999. Interactions between earthworms, litter and trees in an old-growth beech forest. Biology and Fertility of Soils 29:360-370.

Pouyat, R. V., and M. M. Carreiro. 2003. Controls on mass loss and nitrogen dynamics of oak leaf litter along an urban-rural land-use gradient. Oecologia 135:288-298.

Reich, P. B., J. Oleksyn, J. Modrzynski, P. Mrozinski, S. E. Hobbie, D. M. Eissenstat, J. Chorover, O. A. Chadwick, C. M. Hale, and M. G. Tjoelker. 2005. Linking litter calcium, 
earthworms and soil properties: a common garden test with 14 tree species. Ecology Letters 8:811-818.

Robertson, J. D. 1936. The function of calciferous glands of earthworms. Journal of Experimental Biology 13:279-297.

Robinson, C. H., T. G. Piearce, P. Ineson, D. A. Dickson, and C. Nys. 1992. Earthworm communities of limed coniferous soils: field observations and implications for forest management. Forest Ecology and Management 55:117-134.

Schwendener, C. M., J. Lehmann, P. B. de Carmargo, R. C. C. Luizao, and E. C. M. Fernandes. 2005. Nitrogen transfer between high- and low-quality leaves on a nutrient-poor Oxisol determined by ${ }^{15} \mathrm{~N}$ enrichment. Soil Biology and Biochemistry 37:787-794.

Scott, N. A., and D. Binkley. 1997. Foliage litter quality and annual net $\mathrm{N}$ mineralization: comparison across North American forest sites. Oecologia 111:151-159.

Staaf, H. 1987. Foliage litter turnover and earthworm populations in three beech forests. Oecologia 72:58-64.

Swift, M. J., O. W. Heal, and J. M. Anderson. 1979. Decomposition in terrestrial ecosystems. Blackwell Scientific Publications, Oxford, UK.
Szymanski, S. 1982. Growth of some forest tree species in the first 10 years on fairly poor mixed conifer sites. Sylwam 126: 11-29 (in Polish with English summary).

Taylor, B. R., C. E. Prescott, W. J. F. Parsons, and D. Parkinson. 1991. Substrate control of litter decomposition in four Rocky Mountain coniferous forests. Canadian Journal of Botany 69:2242-2250.

Van Cleve, K. 1974. Organic matter quality in relation to decomposition. Pages 311-324 in A. J. Holding, O. W. Heal, S. F. Maclean, and P. W. Flanagan, editors. Soil organisms and decomposition in tundra. Tundra Biome Steering Committee, Stockholm, Sweden.

Van Soest, P. J. 1994. Nutritional ecology of the ruminant. Second edition. Cornell University Press, Ithaca, New York, USA.

Vitousek, P. M. 1982. Nutrient cycling and nutrient use efficiency. American Naturalist 119:553-572.

Vitousek, P. M., D. R. Turner, W. J. Parton, and R. L. Sanford. 1994. Litter decomposition on the Mauna Loa environmental matrix, Hawaii: patterns, mechanisms, and models. Ecology 75:418-429.

\section{APPENDIX}

A figure showing litter $\mathrm{N}$ dynamics in the three experiments (Ecological Archives E087-139-A1). 